\title{
Demographic Characteristics and Risk Factors for HIV and Hepatitis C Virus Co-infection in Pregnancy at a Tertiary Hospital in Northern Nigeria
}

\author{
Ochima O, ${ }^{1}$ Randawa AJ, ${ }^{2}$ Adaji SE, ${ }^{2}$ Ogbu GI. ${ }^{1}$ \\ ${ }^{\prime}$ Department of Obstetrics and Gynaecology, Federal Medical Centre Keffi Nasarawa state Nigeria. \\ ${ }^{2}$ Department of Obstetrics \& Gynaecology, Ahmadu Bello University Teaching Hospital, Zaria, Kaduna State, Nigeria
}

*Corresponding Author: : Ochima O. Department of Obstetrics \& Gynaecology, Federal Medical Centre Keffi Nasarawa state Nigeria. E-mail. otsima179@gmail.com

\begin{abstract} Date Published: 03/04/2020

Hepatitis and TB co-infection in PLWHA is now a major source of co-morbidity and of public health concern. HIV and Hepatitis are two viruses with overlapping epidemics and shared routes of transmission. The clinical course of HCV is accelerated in patients with HIV with resultant end stage Liver disease as a major cause of death. Most studies in my environment failed to identify significant risk factors for HCV infection thus making intervention difficult. The study was a descriptive cross sectional study carried out among consecutive consenting HIV positive pregnant women attending the antenatal clinic of ABUTH-Zaria Nigeria. Relevant information was obtained using a structurally administered questionnaire while Enzyme Linked Immunosorbent assay Biotech Laboratories UK was used for anti Hepatitis $\mathrm{C}$ antibodies assay. Twenty four of the 285 samples tested positive for anti HCV antibodies giving a coinfection rate of $8.4 \%$. Lack of formal education was associated with HCV-HIV co-infection ( $<<0.05)$, odd ratio (OR) $2.5 ; 95 \% \mathrm{CI}$ 0.97-6.97. The possible risk factors analyzed including previous blood transfusion and injecting drug use were not associated with HIV- HCV co-infection ( $>>0.05$ ). This study revealed a high HCV co-infection with significant association with non-formal educational status. Improving female education may be one important strategy for its prevention.
\end{abstract}

Article Information:

Date Submitted: 08/01/2020 Date Accepted: $07 / 03 / 2020$

Keywords:Hepatitis C Virus; HIV co-infection; pregnant women; Risk factors

\section{INTRODUCTION}

$\mathrm{H}$ epatitis and TB co-infection in PLWHA is now a major source of co-morbidity and of public health concern. This is largely due to the improved survival of HIV infected persons due to the availability and access to highly active anti-retroviral therapy enabling conditions with long latency periods such as chronic viral hepatitis to thrive. Chronic hepatitis $\mathrm{C}(\mathrm{HCV})$ affects an estimated
190 million people worldwide and 36.9 million (31.143.9 million) people are living with HIV infection with the highest burden on Sub-Saharan Africa. ${ }^{1,2} 4-5$ million persons are co-infected with HIV/HCV infection. ${ }^{2} \mathrm{HIV}$ co-infection may accelerate the clinical course of Hepatitis C resulting in early development of Liver fibrosis and subsequent hepatoma compared to $\mathrm{HCV}$ 
only infection. It is projected that chronic liver disease will be a major contributor to the cause of death in HIV and HCV coinfection. The exact mechanism of accelerated liver damage is not clear but may be due to decrease in HCV specific T cell responses. It is also thought that HIV specific $\mathrm{T}$ cell accumulate in the liver. ${ }^{3}$ Clinical progression is more rapid in HIV-HCV co-infected patients than in HIV only infection. The prognostic value of HCV infection for both clinical and immunological progression is significant at early stages of HIV infection suggesting active management of hepatitis $\mathrm{C}$ in individuals co- infected especially for asymptomatic patients whose CD4 count is high, to predict and prevent accelerated progression of $\mathrm{HCV}$ and HIV diseases. ${ }^{4} \mathrm{HCV}$ on its own is an independent risk factor for hepatotoxicity with antiretroviral therapy (HAART). ${ }^{5}$ Both HIV and HCV viruses enhances the vertical transmission of one another. Vertical transmission of $\mathrm{HIV}$ increases by 4 to 5 fold with $\mathrm{HCV}$ while the risk of $\mathrm{HCV}$ vertical transmission increases twofolds, ${ }^{6,7}$ the odds of vertical transmission increases by $90 \%$ compared to $\mathrm{HCV}$ alone. ${ }^{8}$ the odd of $\mathrm{HCV}$ infection is 6 times higher among PLWHA. ${ }^{9}$ Increasing maternal viral load increases the risk affecting mostly those with viral level of $>10^{6}$ copies $/ \mathrm{ml} .^{10}$ HCV-HIV positive individuals that are not on treatment are less likely to clear HCV infection spontaneously, with more rapid disease progression and higher viral loads than those with HCV only infection. "Maternal Hepatitis $\mathrm{C}$ viral level is increased with Co-infection with HIV possibly operating via HIV induced immunosuppression.

Hepatitis $\mathrm{C}$ virus is a single-stranded RNA virus in the flavivridae family affecting the Liver. It spreads primarily by contact with blood and blood products, unhealthy sexual behavior, intravenous drug use, unsafe injection practices and mother to child transmission. ${ }^{12}$ The prevalence of $\mathrm{HCV}$ in the general population is $2.4 \%$, it is $4 \%$ among pregnant and heterosexually exposed population. The prevalence rises to $6.4 \%$ in men that have sex with men (MSW) and $82.4 \%$ among people who inject drugs (PWID). ${ }^{13}$ The HIV and HCV sero-prevalence among HIV positive pregnant women in some studies in Nigeria are $1.65 \%,{ }^{14} 1.5 \%,{ }^{15} 8.3 \% .{ }^{16} 21.9 \%{ }^{17}$ and $2.4 \%{ }^{18}$ in Ibadan, Lagos, Calabar, Jos and Abuja FCT respectively. Outside Nigeria it is $5.3 \%{ }^{19}$ and $29.69 \%{ }^{20}$ in Malawi and Spain respectively. In the European collaborative study involving 1050 HIV positive women, HCV seroprevalence of $12.3 \%$ was recorded with the highest rate of $28.9 \%$ among intravenous drug use (IDU) ${ }^{21}$ and In USA 30\% of HIV positive pregnant women who are intravenous drug use (IDU) are reportedly co-infected with $\mathrm{HCV}^{22}$

The HIV and HCV pandemic overlap as a result of shared transmission routes. The shared route of transmission could suggest that many HIV positive clients may also be at risk of HCV infection. The non-specificity of clinical presentation and the chronic course often makes early diagnosis of $\mathrm{HCV}$ difficult. The risk factors in the transmission in my environment remain obscure thus hindering effective prevention strategies. The objective of this study was to determine the demographic characteristics and risk factors for $\mathrm{HCV}$ co-infection in HIV positive pregnant women attending the antenatal clinics at ABUTH Zaria.

\section{MATERIALS AND METHODS}

The study was a descriptive cross sectional study carried out among consecutive consenting HIV positive pregnant women attending the antenatal clinic of ABUTH-Zaria Nigeria. During the nine months study period there were a total of 3,472 pregnant women seen in the ANC. Patients confirmed to be HIV positive at booking were approached and recruited for participation after obtaining am informed written consent. An ethical approval was obtained from the ethical committee of the hospital. A structurally designed questionnaire was used for obtaining information on sociodemographic and possible risk factors from the patients. The Inclusion criteria used are confirmed HIV positive pregnant women and personal consent while the exclusion criteria are Non consenting clients, HIV negative pregnant women and non pregnant HIV Positive women.

Five milliliters $(5 \mathrm{ml})$ of blood was taken from the ante-cubital vein under aseptic technique and sent to the laboratory in ethylene diamine tetra acetic acid (EDTA) specimen bottle. Sera obtained after centrifugation were analyzed for $\mathrm{HCV}$ antibody tests. Specimen containers were coded to ensure confidentiality. The sera were stored at $2-8^{\circ} \mathrm{C}$ and prior to testing were allowed to attain room temperature of between $26^{\circ} \mathrm{C}$ and $28^{\circ} \mathrm{C}$.

\section{The HCV Test \& Statistical Analysis}

It was performed using a third generation Enzyme Linked Immunosorbent Assay (Biotech Laboratories, UK) according to the manufacturer instruction.

A database was developed using the computer soft ware: Statistical Package for Social Sciences (SPSS) version 20.0 followed by data analysis and interpretation. Categorical variables were presented as frequencies and percentages. 
Logistic regression was used to obtain odds ratios (ORs) and $95 \%$ confidence intervals (CIs) with level of statistical significance set at $\mathrm{P}<0.05$

\section{RESULTS}

There were a total of two hundred and eighty five (285) respondents out of the two hundred and ninety (290) enrolled for the study giving a response rate of $98.2 \%$. Five (5) respondents declined further participation for personal reasons.

Table 1 shows the socio demographic characteristics of the responders. The age of the respondents ranged from 15 to 41 years with a mean of 29.8. Most of the clients (31.6\%) were in

Table 1: Socio-demographic characteristics of respondents

\begin{tabular}{|c|c|c|}
\hline Age (years) & Frequency & Percentage $(\%)$ \\
\hline $15-19$ & 8 & 2.8 \\
\hline $20-24$ & 52 & 18.2 \\
\hline $25-29$ & 90 & 31.6 \\
\hline $30-34$ & 55 & 19.3 \\
\hline $35-39$ & 48 & 16.8 \\
\hline $40-44$ & 32 & 11.2 \\
\hline Total & 285 & 100 \\
\hline \multicolumn{3}{|l|}{ Marital status } \\
\hline Married & 283 & 99.3 \\
\hline Single & 2 & 0.7 \\
\hline Total & 285 & 100 \\
\hline \multicolumn{3}{|c|}{$\begin{array}{l}\text { Highest educational } \\
\text { attainment }\end{array}$} \\
\hline None & 59 & 20.7 \\
\hline Quor'anic & 73 & 25.6 \\
\hline Primary & 80 & 28.1 \\
\hline Secondary & 49 & 17.2 \\
\hline Tertiary & 24 & 8.4 \\
\hline Total & 285 & 100 \\
\hline \multicolumn{3}{|c|}{ Occupation of respondent } \\
\hline Civil servant & 59 & 20.7 \\
\hline Business women & 102 & 35.8 \\
\hline Artisan & 37 & 13 \\
\hline Military/Uniform & 8 & 2.8 \\
\hline \multicolumn{3}{|l|}{ Personnel } \\
\hline Unemployed & 79 & 27.7 \\
\hline Total & 285 & 100 \\
\hline
\end{tabular}

the age range $25-29 y e a r s$ and $46.3 \%$ of the clients had no formal education.

HCV co-infection rate (Table two). Overall, twenty four (24) of the $285 \mathrm{HIV}$ positive samples analyzed tested positive for $\mathrm{HCV}$ antibodies giving a co-infection rate of $8.4 \%$. All age groups tested positive to the HCV antibody with the exception of age group 15 to $19 y$ years. It was higher among age group 35-39years with a sero-prevalence rate of $14.5 \%$. HCV sero-prevalence was higher among those with no formal education with sero-prevalence rate of $12.1 \%$ and lower with clients who had at least secondary school education (4.1\%). In relation to occupation of respondents, HCV seroprevalence was higher among Military/Uniform personnel with $1(12.5 \%)$ out of the 8 positive cases. This was closely

Table 2: Socio - demographic variables \& HCV test results

\begin{tabular}{llll} 
& \multicolumn{2}{c}{ HCV Status } & N=285 \\
\hline Age (years) & Positive & Negative & Total \\
\hline $15-19$ & $0(0)$ & $8(100)$ & 8 \\
$20-24$ & $3(5.8)$ & $49(94.2)$ & 52 \\
$25-29$ & $7(7.8)$ & $83(92.2)$ & 90 \\
$30-34$ & $6(10.9)$ & $49(89.1)$ & 55 \\
$35-39$ & $7(14.6)$ & $41(85.4)$ & 48 \\
$40-44$ & $1(3.1)$ & $31(96.9)$ & 32 \\
Total & $\mathbf{2 4 ( 8 . 4 )}$ & $\mathbf{2 6 1}(\mathbf{9 1 . 6 )}$ & $\mathbf{2 8 5}$ \\
Highest & & & \\
Educational & & & \\
attainment & & &
\end{tabular}

$\begin{array}{llll}\text { None } & 6(10.2) & 53(89.8) & 59 \\ \text { Quor'anic } & 10(13.7) & 63(86.3) & 73 \\ \text { Primary } & 5(6.3) & 75(93.7) & 80 \\ \text { Secondary } & 1(2) & 48(98) & 49 \\ \text { Tertiary } & 2(8.3) & 22(91.7) & 24 \\ \text { Total } & \mathbf{2 4 ( 8 . 4 )} & \mathbf{2 6 1 ( 9 1 . 6 )} & \mathbf{2 8 5} \\ \text { Occupation of } & & & \\ \text { respondent } & & & \end{array}$

\begin{tabular}{llll} 
Civil servant & $4(6.8)$ & $55(93.2)$ & 59 \\
Business women & $9(8.8)$ & $93(91.2)$ & 102 \\
Artisan & $2(5.4)$ & $35(94.6)$ & 37 \\
$\begin{array}{l}\text { Military/uniform } \\
\text { personnel }\end{array}$ & $1(12.5)$ & $7(87.5)$ & 8 \\
Unemployed & $8(10.1)$ & $71(89.9)$ & 79 \\
\hline Total & $\mathbf{2 4}(\mathbf{8 . 4})$ & $\mathbf{2 6 1 ( 9 1 . 6 )}$ & $\mathbf{2 8 5}$ \\
\hline
\end{tabular}


Table 3: Risk Factors associated with HCV sero-positivity (n=285)

\begin{tabular}{lllll}
\hline Risk Factors & $\begin{array}{l}\text { Prevalence of } \\
\text { HCV }\end{array}$ & Odd ratio & $\mathbf{9 5 \%}$ CI & p-valve \\
\hline $\begin{array}{l}\text { History of STI } \\
\text { other than HIV }\end{array}$ & 7.5 & 0.86 & $0.16-3.12$ & 0.410 \\
$\begin{array}{l}\text { Previous blood } \\
\text { transfusion }\end{array}$ & 11.4 & 1.48 & $0.35-4.48$ & 0.243 \\
$\begin{array}{l}\text { Use of recreational } \\
\text { drugs }\end{array}$ & 3.2 & 0.33 & $0.01-2.23$ & 0.010 \\
$\begin{array}{l}\text { Tribal Marks } \\
\text { Education (no }\end{array}$ & 3.7 & 0.37 & $0.04-1.61$ & 0.064 \\
formal education) & 12.1 & 2.5 & $0.97-6.97$ & 0.010 \\
$\begin{array}{l}\text { Tattoos } \\
\text { Gishiri cuts }\end{array}$ & NIL (zero) & - & - & - \\
\hline
\end{tabular}

followed by the unemployed group with $8(10.1 \%)$ out of 79 positive women.

Table 3 shows possible risk factors for HCV co-infection. Lack of formal education was significantly associated with HCV co-infection (12.1\%, OR 12.1 95\% CI 0.97-6.97 P0.010 ), with an increased likelihood of co-infection with positive history of previous blood transfusion (though not statistically significant). There were no cases of HCV seropositive results among the three with 'Gishiri' cuts while none of the respondents had female circumcision.

\section{DISCUSSION}

The sero-prevalence rate of $\mathrm{HCV}$ antibodies among HIV positive pregnant women in the study was $8.4 \%$. This is similar to the $8.3 \%$ noted from Obudu Cross River state ${ }^{16}$ but lower than studies among similar cohorts of HIV positive pregnant women in Jos, Nigeria (21.9\%), ${ }^{17}$ Austria (10\%), Europe $(12.3 \%)^{21}$ and USA $(30 \%)^{22}$ This disparity may be explained by the fact that injecting drug use (IDU) a strong risk factor for co-infection was prevalent among the European and American subjects compared to their Nigerian counterparts. In the case of Jos, the higher rate may be a reflection of the previously documented higher HCV infection of $11 \%{ }^{24}$ among the general population in Plateau state as compared to the $6.2 \%$ sero-prevalence of $\mathrm{HCV}$ in Kaduna state. ${ }^{25}$ It is however higher than the rates of $1.65 \%,{ }^{14} 1.5 \%,{ }^{15} 2.4 \%{ }^{18}$ and $3.8 \%{ }^{26}$ from Ibadan, Lagos, FCT Abuja and Thailand respectively.

The prevalence rate in this study is an important finding for several reasons. Firstly, it has showed significant rate of $\mathrm{HCV}$ -
HIV co-infection among PMTCT clients in the study population which hitherto remained undocumented. Secondly, several studies have demonstrated that HCV/HIV co-infection worsens liver pathology with higher risks of progression to liver cirrhosis. ${ }^{4}$ Co-infection may also accelerate vertical transmission of both infections especially with high maternal viraemia. ${ }^{7.8}$ The findings of the study therefore offers an opportunity to physicians and clients to make important decisions about prevention, treatment and long time follow up.

In this study, HCV sero-prevalence was higher among age group 35-39 years contrary to other studies that shows higher prevalence among older persons due to the prolonged incubation period of the virus. ${ }^{27,28}$ The reasons for this were not deducible from this study but the finding may not be unconnected with the fact that this group of 35-39 years are at the peak of their reproductive career and may have been exposed to several HCV risk factors. HCV/HIV Co-infection was also found to be high in subjects with no formal education $12.1 \%$. This was statistically significant $(p<0.05)$. This finding suggests that formal education may be an important factor in the knowledge of the virus and how to prevent its transmission. Similar findings on the possible links between educational level and HCV/HIV-1 co-infection among HIV positive pregnant women was noted in the study by Nimzing et al. ${ }^{17}$

The findings of this research also show a relatively higher rate of HCV/HIV co-infection among subjects in the military and business community (Table 2). The reason for the higher prevalence of $\mathrm{HCV} / \mathrm{HIV}$ co-infection in these groups is obscure though may not be unconnected to the sample size.

Women with previous history of blood transfusion are more likely to be HCV positive though not statistically significant $\mathrm{p}>0.05$ (Odd ratio of $1.4895 \%$ CI 0.35407 to 4.48). Transfusion-associated HCV infection was a predominant worldwide risk factor before $\mathrm{HCV}$ testing became available. It has been virtually eliminated in those countries that implemented routine $\mathrm{HCV}$ testing of donors but where this is not routine, receipt of blood transfusion remains an important source of infection especially in rural and semi urban areas. In Nigeria, efforts are being made to eliminate the risk of transmission through blood transfusion by successfully implementing a national blood safety program led by Safe Blood for Africa Foundation (SBFA) to fight the spread of HIV/AIDS.

There was no significant association between HCV infection and previous history of STI other than HIV. It is possible that 
those diagnosed with STI previously and who have been treated and counseled about blood-borne infections may be more likely to imbibe risk reduction messages though the strength of evidence is very weak in view of the small sample size. Furthermore, there was no significant association between $\mathrm{HCV}$ infection and injecting drug use and tribal marks. This is similar to other studies in the country and the subregion. ${ }^{29,30}$ There was no case of $\mathrm{HCV}$ infection among respondents with tattoos and those with 'gishiri' cut.

None of the respondents admitted to female circumcision. The reasons for these findings could not be explained by this study. However in the case of injecting drug use, even though it is known to be an overwhelming risk factor for $\mathrm{HCV}$ infection in the western world, comparatively it is an infrequently reported practice in Nigeria. It may also be that the respondents under-reported the practice of injecting drug use and female genital cutting to avoid stigma that could be connected to them.

\section{Recommendations}

The high prevalence of HCV/HIV co-infection in this study suggest that it may be justified to perform HCV screening test for all pregnant women who tests positive to HIV in the study centre. The benefits of this include; early detection and management, opportunity for re-enforcing counselling on risk reducing behavioural changes and provision of awareness on HCV-HIV co-infection.

More effort and political will is needed to improve female education, equality and socio-economic empowerment. This will have a positive multiplier effect on all health indices in general and on $\mathrm{HCV}$ prevention in particular.

All blood donors should have HCV screening and where not supported by facilities such donor should be referred to appropriate centre. Further studies to document the risk of vertical transmission and the impact on pregnancy outcome in our environment as well as effect on the liver will be welcome.

\section{CONCLUSION}

This study revealed a fairly high HCV co-infection with significant association with non-formal educational status but no significant impact on HIV disease burden. Improving female education and economic empowerment may be one important strategy for its prevention.

\section{Conflict of Interest}

No conflict of interest and no form of financial support was received for the study.

\section{REFERENCES}

1. Alberti A, Clumeck N, Collins S. Short statement of the first European Consensus Conference on the treatment of chronic hepatitis B and C in HIV co-infected patients. J Hepatol 2005; 42: 615-624.

2. Alter MJ. Epidemiology of viral hepatitis and HIV coinfection. Journal of hepatology. 2006;44(1 Suppl) : S69.

3. Tossing G. Management of chronic hepatitis c in HIV coinfected patients -results from the first international workshop on HIV and hepatitis co-infection, December 2-4, 2004 Amsterdam, Netherlands. Eur J Med Res. 2005; 10(1):43-5.

4. Piroth L, Duong M, Quantin C, Abrahamowicz M, Michardiere R. Does hepatitis C virus co-infection accelerate clinical and immunological evolution of HIVinfected patients? AIDS _. 1998 Mar 5;12(4):381-8.

5. Greub G. Ledergerber B. Battegay M, Grob P, Perrin L. Clinical progressions, survival, and immune recovery during antiretroviral therapy in patients with HIV-1 and hepatitis C virus co-infection: the Swiss HIV cohort study. Lancet 2000; 356(9244):1800-1805.

6. Shepard CW. Global epidemiology of hepatitis $\mathrm{C}$ virus infection Lancet Infect Dis. 2005 Sep;5(9):558-67

7. Sulkowski MS. Viral hepatitis and HIV co-infection. Journal of hepatology. 2008 Feb;48(2):353-67

8. Doyle JS. Current and emerging antiviral treatments for hepatitis $\mathrm{C}$ infection British Journal of Clinical Pharmacology. 2013;75(4):931-43

9. Chelsea BP, Snehal NS. Kristine EJ. Amita G. Impact of Maternal HIV Co-infection on the Vertical Transmission of Hepatitis C Virus: A Meta-analysis. Oxford Journals Medicine Clinical Infectious Diseases 44(8):1123-1131.

10. Thomas SL, Newell ML, Peckham CS, Ades AE. Hall AJ. A review of Hepatitis $C$ virus vertical transmission: Risk of transmission to infants born to mothers with and without $\mathrm{HCV}$ viraemia or human immunodeficiency virus infection. Int J Epedemiol 1998; 27(1):108-17.

11. Thomas DL, et al. The natural history of hepatitis $\mathrm{c}$ virus infection: Host, viral, and environmental factors. JAMA. 2000;284(4):450-6 
12. World Health Organization. Hepatitis $\mathrm{C}$-mode of transmission

13. Platt L, Easterbrook P, Gower E, McDonald B, Sabin K, Mc-Gowan C, Yanny I, Razavi H, Vickerman P. (2016) Prevalence and burden of HCV co-infection in people living with HIV: a global systematic review and metaanalysis. The Lancet infectious diseases 16(7): 797-808. ISSN 1473-3099 DOI: https://doi.org/10.1016/S14733099 (15)00485-5

14. Adesina. Hepatitis $\mathrm{C}$ in HIV positive pregnant women 154 Tropical Journal of Obstetrics and Gynaecology / May-Aug 2016 / Volume 33 / Issue 2/153-8

15. Ezechi OC, Kalejaiye OO, Gab-Okafor CV, Oladele DA, Oke BO,Musa ZA, et al. Sero-prevalence and factors associated with Hepatitis B and C co-infection in pregnant Nigerian women living with HIV infection. Pan Afr Med J 2014;17:197.

16. Utoo BT. Utoo PM. Bassey SS. Hepatitis C virus and Human immunodeficiency virus co-infection among pregnant women in South- South, Nigeria. Jos journal of Medicine; 5(2):31-35

17. Nimzing L, Lar PM, Nimchak KG. Daru PH. Prevalence of anti-hepatitis C antibody in HIV-1 positive pregnant women in Jos: Journal of Medicine in the Tropics, 2006, $8(1): 1-8$.

18. Bassey EB. Moses AE. Udo SM. Umo AN. Parallel and overlapping Human Immunodeficiency virus, Hepatitis $\mathrm{B}$ and $\mathrm{C}$ virus infection among pregnant women in the Federal Capital Territory, Abuja, Nigeria, online J Health Allied Scs. 2009;8(1):

19. Chasela CS, Wall P, Drobeniuc J, King CC, Teshale E, Hosseinipour MC, et al. Prevalence of hepatitis $\mathrm{C}$ virus infection among human immunodeficiency virus-1-infected pregnant women in Malawi:The BAN study. J Clin Virol 2012;54:318-20.

20. Seisdedos T, Díaz A, Bleda MJ, Ortiz M, García A, Díez $\mathrm{M}$, et al. Prevalence of maternal hepatitis $\mathrm{C}$ infection according to HIV sero status in six Spanish regions (2003-2006). Eur J Public Health 2011;21:643-5.

21. Landes M, Newell ML, Barlow P, Fiore S, Malyuta R, Martinelli $\mathrm{P}$, et al. Hepatitis $\mathrm{B}$ or hepatitis $\mathrm{C}$ co-infection in HIV-infected pregnant women in Europe: HIV Medicine (2008), 9, 526-534.

22. Sherman KE. Rouster SD. Chung RT. Hepatitis C virus prevalence among patients infected with human immunodeficiency virus: a cross-sectional analysis of the US adult AIDS Clinical Trials Group. CID. 2002; 34:831-
7.

23. steieninger C. Kundi M. Jatzko G. Kiss H. Lischka A. Increased risk of mother to child transmission of $\mathrm{HCV}$ by iintrapartum infantile exposure to maternal blood. J infect Dis. 2003; 187 (3) 345-351.

24. Ndako JA. Echeonwu GO. Shidali NN. Bichi IA. Paul GA. Occurrence of Hepatitis C Virus infection in type 2 diabetic patients attending Plateau state specialist hospital Jos Nigeria Virology Journal 2009, 6:98

25. Sheyin Z, Jatau ED, Mamman AI, Randawa AJ. Molecular epidemiology of hepatitis c virus (HCV) in Kaduna state; African journal of clinical and experimental microbiology may 2012 isbn 1595-689X; 13(2):61-65

26. Denise JJ. Infection with Hepatitis C Virus among HIVInfected Pregnant Women in Thailand: Infectious Diseases in Obstetrics and Gynaecology Volume 2008 ( 2008 ), Article ID 840948,7 pages doi:10.1155/2008/840948

27. Alter HJ. Descartes, Before the Horse: I clone, therefore I am: the hepatitis $C$ virus in current perspective. Ann intern Med 1991; 115: 644-9

28. Cozzolongo R. Osella AR. Elba S. epidemiology of HCV infection in the general population: A survey in a southern Italian town. Am J Gastroenterol. 2009:104 (11):2740-6.

29. Zelma BC. Gustavo CM. Mariza MA. Clidenor GF. Jose VMF. Ana LM. Prevalence and risk factors for Hepatitis $\mathrm{C}$ and HIV-1 infections among pregnant women in Central Brazil: BMC Infectious Diseases 2009; 9:116

30. Alavian SM, Gholami B. Masarrat S. "Hepatitis C risk factors in Iranian volunteer blood donors: a case-control study," Journal of Gastroenterology and Hepatology, 2002; 17 (10): 1092-1097. 